\title{
The Impact of Jacuzzi Bathtubs on House Prices
}

\author{
Austin Otegbulu, $\mathrm{PhD} \&$ Olusola Johnson, MSc \\ Department of Estate Management, University of Lagos, Nigeria \\ E-mail: austinotegbulu@yahoo.com, estatessj1004@yahoo.co.uk
}

Received: Mach 4, 2011

Accepted: April 19, 2011

doi:10.5539/jsd.v4n3p199

\begin{abstract}
The study examines the impact of Jacuzzi bathtubs on house prices. Jacuzzi bathtubs have health related benefits. This study empirically tests a hedonic house pricing model using a sample of 138 houses in high income residential sub-market of Lekki phase one in Lagos metropolis. Forty-six duplexes have Jacuzzi bathtubs installed in their homes while Ninety-two do not. The study results show that that having Jacuzzi bathtubs increases home value by N2, 167,615.
\end{abstract}

Keywords: Jacuzzi bathtubs, House prices, Lagos metropolis

\section{Background of Study}

A house is a heterogeneous good. Its value depends on a number of characteristics such as size, age, and location. Rosen (1974) hedonic pricing model hypothesized that a housing market can be viewed as the interaction of implicit markets for these characteristics. As a result, regression analysis can be utilized to derive the implicit price of each housing attribute and the contribution of each attribute to the overall house price. The housing attributes used are generally classified into: structural attributes, such as age and floor area; location-related attributes, such as proximity to the $\mathrm{CBD}$, floor level, and view; and neighbourhood attributes such as the provision of social facilities (Mok, Chan and Cho 1995).

Home Jacuzzi bathtubs belong to the structural attributes of a house. It is a term that is used to refer to any bathtub with water jets. A Jacuzzi bathtub is one of the green features that could be installed into homes. It offers several advantages over traditional bathing facilities. A Jacuzzi is synonymous with class and status but besides the benefit of an increase in owner status in society, owners also benefit from the therapeutic value of a Jacuzzi. The benefits of Jacuzzis vary from person to person as there are many therapeutic values that a Jacuzzi has that can assist people with various aches and pains ranging from tension to rheumatoid arthritis. The power of warm water has been harnessed for centuries and dates back to the Ancient Greeks. Therefore it is well known that the comfort that owners experience in a Jacuzzi is rarely out matched and that there are few people who are not aware of the comfort of a Jacuzzi. Stress is a leading factor in illnesses across the world and decreasing stress can assist with immune system and longevity in the long run. Excess stress is damaging to health. It is therefore important to take time daily to relax and de-stress. The experience of the warm water of a Jacuzzi bathtubs circulating around the body is the ideal activity for to relax aching body, rejuvenate the body or assist in pain relief. Hydrotherapy is often used for the treatment of diseases and with a private Jacuzzi bathtub one will be able to experience the benefit of hydrotherapy in his own home.

The New England Journal of Medicine published articles on hot tubs and diabetes in a 1999 issue and two issues during 2000. The study was led and reported by Philip L. Hooper, M.D., of the McKee Medical Center in Loveland, Colorado. Their thesis was that exercise is effective for people with type 2 diabetes. They wondered if sitting in a hot tub with water up to their shoulders would simulate the benefits of exercise for their patients. Eight patients participated. They used the hot tub for half an hour a day, six days a week, for three weeks. Water temperature ranged from $100^{\circ} \mathrm{F}$ to $105.8^{\circ} \mathrm{F}$. Diet, exercise routines, and medication were stable for eight weeks before and during the test period, although one participant had to reduce his insulin dose by 18 percent to prevent hypoglycemic reactions. After three weeks the mean weight of the patients had decreased by 3.7 pounds. Mean fasting plasma glucose level decreased from $182 \mathrm{mg} / \mathrm{dl}$ to $159 \mathrm{mg} / \mathrm{dl}$. Their mean Alc levels dropped from 11.3 to 10.3. As the study progressed, the participants reported improved sleep and an increased general sense of well-being. Hooper theorizes that the benefits could result from increased blood flow to skeletal muscles. However, Jacuzzi bathtubs are also potential health risk for some patients especially those suffering from kidney problems, high blood pressure and pregnant women (Charite University Hospital in Berlin, 2003). In all, Jacuzzi bathtubs are highly beneficial. Apart from the benefits to the body, the installation of a Jacuzzi bathtub could add a premium to house price. 
Somewhat surprisingly, previous studies have not really examined the impact of home installed Jacuzzi bathtubs on house prices. Very few studies included home Jacuzzi bathtubs in the regression model in the developed countries; the reasons could be attributed to the fact that most homes in the developed world do not have the facilities. In Lagos, Nigeria, the use of home Jacuzzi bathtub is a green feature in the high income residential sub-market. There has been no known study that has examined the impact of home Jacuzzi bathtubs on house prices in this sub-market. The lack of prior research and the predicted trend in home building make home Jacuzzi bathtubs a topic worthy of particular attention for both residential property appraisers and academics. The intention of this study is therefore to determine the impact of home installed Jacuzzi bathtubs on house prices in high income residential sub-market in Lagos metropolis. The paper is organized in the following manner. Section II provides a review of literature on the studies that used Jacuzzi bathtubs in their regression models. Data and methodology are described in Section III. Section IV presents the results of the study. Section V concludes the findings.

\section{Literature Review}

Extant literature shows that the hedonic pricing model, developed from the works of several scholars, including Lancaster (1966), Rosen (1974) and Freeman (1979), has hitherto been extensively used to study the attributes affecting the price of products, as well as the marginal contribution of each attribute. An extensive review of extant literature however reveals that many past studies that employed the hedonic price model focused on locational, structural, and neighborhood attributes.

The location of a property has been conceived in most studies in terms of accessibility factors and neighbourhood level factors (Lentz and Wang, 1998). In the traditional view of location, accessibility is measured in terms of access to the Central Business District (CBD). Accessibility, in whatever form it has been measured, has some influence on housing prices (Palmquist, 1992; Ridker and Henning, 1968). Transport accessibility is frequently associated with the ease of commuting to and from amenities, and is measured by travelling time, cost of travel, convenience, and availability of different transport modes (Adair, McGreal, Smyth, Cooper and Ryley 2000; So, Tse and Ganesan 1997).

Accessibility to goods and services is a complex notion which completely pervades territorial issues; and is for that reason considered as one of the main determinants of property values (Des Rosiers, Theriault, and Villeneuve 2000). The influence of accessibility however differs depending on the configuration of the urban fabric. The ultimate implications of accessibility to urban amenities on house prices is also influenced by a number of other factors including households' preferences, family structure and life cycle as well as by the income and motorization constraints. The resulting utility functions affect home location choices and consequently, housing market as a whole (Des Rosiers and Theriault, 2006).

Location as a measure of accessibility to various urban amenities (or nuisances) has profound effects on the price of properties of all categories. Locational variables have generally been upheld as the most important predictors of residential property values above structural attributes (Kauko, 2000, 2003, 2004; Meen, 2001; Batty, 2003; Bourassa Hoesli \& Sun 2003; Daly, Gronow, Jenkins and Plimmer 2003; Kryvobokov, 2007; Bello and Bello, 2007). For residential property, location is of a special interest as location often dictates the activities of the occupant's daily life, day or night, work or leisure. For example, a potential house buyer will consider distance to the workplace, shopping centres and educational establishments.

Transport accessibility is concerned with the ease of travelling to and from amenities, and can be measured in a variety of ways including time taken, cost of travel, convenience and availability of different transport modes (Adair, et al., 2000; So et al., 1997). The positive influence of good public transport services on housing prices has also been empirically examined (Celik and Yankaya, 2006; Pels and Rietveld, 2006; So et al., 1997).

The positive influence of good public transport services on housing prices has been empirically examined. So et al., (1996) estimated the influence of transport on house prices in Hong Kong. The authors found that buyers were willing to pay more for properties with easy accessibility to work. Celik and Yankaya (2006) modelled the impact of rail transit investment on the prices of residential property in Izmir subway, Turkey and found that the proximity to rail stations was valued at $\$ 250-300$ per meter, and the value of travel per hour was $\$ 1.47-1.83$ on average. Pels and Rietveld (2006) studied the impact of railway transport on real estate prices in Dutch housing market and found dwellings very close to a station are on average about $25 \%$ more expensive than dwellings at a distance of 15 kilometres or more. Bae et al., (2002) also investigated the impact of the construction of a new subway line (Line 5) in Seoul on nearby residential property values. A hedonic pricing model shows that distance from a Line 5 subway station had a statistically significant effect on residential prices only prior to the opening of the line. 
Several studies have been conducted to investigate the impact of neighbourhood factors on residential property value. For example, the quality of public schools has been found to have a great impact on real house prices. Clark and Herrin (2000) and Haurin and Brasington (1996) observed that school quality is more important to local residents (especially those with children) than either crime or environmental quality .The quality of schools has been measured in terms of school input variables, such as expenditures per pupil or average cost per student (Ketkar, 1992), student achievement levels or Standardised Aptitude Test (SAT) scores (Jud and Watts, 1981; Ketkar, 1992; Walden, 1990). Generally, higher test scores have a positive impact on property prices (Clauretie and Neill, 2000; Jud and Watts, 1981).

Huh and Kwak (1997) study in Seoul revealed that hospitals exhibit a significant negative effect on property prices because of cultural norms in Korea. For instance, when someone dies in Korea, the corpse is placed in the hospital mortuary, and condolences are extended to family members and relatives for three days. Proximity to hospitals and health centres is therefore not desirable due to the commotion that ensues including the nuisance value of ambulance sirens, the general congestion in the vicinity of hospitals, as well as superstitious beliefs.

Places of worship, such as churches, could be an amenity that generally enhances the value of neighbourhood properties because they serve as a hub of commercial activities that draws people together for worship and socials; providing peace in the form of a respite from commercial and family concerns; operating schools ranging from day-care for children and aged, secondary and vocational, and in some cases, a university (Carroll, Clauretie \& Jensen, 1996). On the other hand, So et al., (1997) found that neighborhood churches could be a nuisance that depreciates the value of nearby houses due to noise from church bells, loud speakers and musical instruments, people arriving and departing the premises, traffic and parking problems, pollution from automobiles, operating hours extending from morning till evening, and people of different shades and characters trooping into the neighbourhood.

Proximity to shopping complexes and the size of shopping centres have both been found to exert influence on the value of the surrounding residential properties (Des Rosiers, Lagana, Thériault and Beaudoin, 1996; Sirpal, 1994). Des Rosiers, et al. (1996) found that each additional shop adds about $\$ 27$ to the market value of the properties in the vicinity of the shopping centre. This may be affected at a certain level by economic law of diminishing marginal utility.

Prices of properties are readily related to their structural attributes - number and size of rooms, plot size, age, condition, facilities etc. Ball (1973) observed that if a house had more desirable attributes than others, the valuation of these attributes would be reflected in higher market prices for this house. Studies have confirmed that structural attributes preferred by buyers may not always be identical, and the significance of structural attributes can change over time, and may vary between nations (Kohlhase, 1991). For instance, while attributes relating to the number of rooms and floor area are relatively universal, other attributes may defer depending on culture, tradition, technology, climate and the particular neighborhood characteristics. Making a distinction between structural quality and structural quantity Bond (2008) noted that while structural quantity has been well researched, there has been relatively little research on structural quality due to the difficulty in measuring objectively and precisely the physical and environmental quality of the properties.

Studies have revealed that the number of accommodation particularly bedrooms (Fletcher, Mangan and Raeburn 2000; Carroll et al., 1996), the number of bath/ toilets (Garrod and Willis, 1992), and the floor area (Carroll et al., 1996; Rodriguez and Sirmans, 1994) are positively related to the sale price of houses. The reason is not farfetched. Buyers would be willing to pay more for more space, especially functional space. Residential properties with bigger floor areas are desired by big families and buyers who can afford a better standard of living. Garrod and Willis (1992) discovered that an additional room increases a property's value by about 7\%, and an extra bathroom collecting twice that premium.

Wolverton (1997) studied the relationship between residential lot price and lot size in USA and found that residential lot price per square foot diminishes as lot size increases. Yang (2000) applied the hedonic price model with uncertain attributes in the People's Republic of China and found that buyers are willing to pay additional expenditure to protect them from low construction quality. According to Chau, Yung, Leung and Law (2001) buyers are willing to pay about $\mathrm{HK} \$ 416$ (approximately $7 \%$ more than average housing prices) more per square foot for properties constructed by large reputable developers. Researchers also surmised that building age is negatively related to property prices (Clark and Herrin, 2000; Rodriguez and Sirmans, 1994). This is because, older houses are worth less because they incur more costs in maintenance and repair, and also have decreased usefulness due to changes in design and construction standards over time (Clapp and Giaccotto, 1998). Benefield and Weeks (2009) studied the impact of specialty ceilings on residential property values in medium-sized East 
Coast metropolitan statistical area, in the USA and found that the impact varies between newly constructed and existing homes, but that specialty ceilings can contribute up to $6.5 \%$ of the ultimate selling price.

The paucity of studies on the impact of Jacuzzi bathtubs on house prices is apparent from hedonic price model literature. Not many studies have included Jacuzzi bathtubs amenities as a housing attribute in their hedonic regression analysis. Clauretie, Kuhn and Schwer (2004) included the amenity in their regression model. They compare the appraised value of sixty properties taken through eminent domain in Clark County, Nevada to comparable properties sold in free market transactions. The authors found significant and positive coefficient values for properties sold in free market for both linear and semi log regression model. For properties taken through eminent domain, Jacuzzi amenity also recorded positive coefficient but not significant. When the truncated linear model was used Jacuzzi amenity is also significant and recorded a positive coefficient for properties sold in free market. Properties that were taken through eminent domain is not significant but recorded a positive coefficient. Komarova (2009) also included Jacuzzi bathtubs amenity in the regression model when valuing environmental impact of air pollution in Moscow. The author found Jacuzzi bathtubs amenity adds between $\$ 53,000-54,000$ to house prices from the linear regression model. The result of the double $\log$ regression functional form also revealed Jacuzzi bathtubs amenity to increase house price by $11.1 \%$. Furthermore, Selim (2008) included this amenity in the hedonic regression, the result for the entire sample revealed a significant and positive coefficient, for the urban area, Jacuzzi was also significant and has a positive coefficient while in the rural area Jacuzzi is not significant and also has a negative coefficient. Tu, Ong and Han (2009) also included Jacuzzi bathtub in their regression models when they evaluated the turnover and housing price dynamics in Singapore condominium market, the results revealed a positive coefficients for Jacuzzi bathtubs in all the models. The above literature revealed that awareness of the benefits of Jacuzzi bathtubs could add premium to house prices.

\section{Data and Methodology}

The study area is a high income residential sub-market of Lekki peninsula within Lagos metropolis in Nigeria. It is inhabited by both affluent Nigerians and expatriates who work for multi-national companies in Nigeria. The study area largely contains residential and commercial buildings. The Lekki Sub-Region $\left(6^{\circ} 30^{\prime} 0^{\prime \prime} \mathrm{N}, 4^{\circ} 7^{\prime} 0^{\prime \prime} \mathrm{E}\right)$ comprises of a naturally formed peninsula on the Atlantic Ocean East of Lagos City and Lagos Lagoon. The peninsula is approximately 70 to $80 \mathrm{~km}$ long, stretching from Victoria Island in the west to Refuge Island in the east, with an average width of $10 \mathrm{~km}$.

Hedonic pricing model is utilized to examine the impact of Jacuzzi bathtubs on house prices. Jacuzzi is a feature in the high income residential sub-market in Lagos, Nigeria. The study used the questionnaire survey to collect data from owners of duplexes in the study area. Questionnaire survey was adopted because apparent lack of reliable property transaction data, either with public or private sector. Likewise, for lack of data on duplexes and the logistics of undertaking a census of duplexes in the area under reference, the study employed the convenient sampling technique combined with the snowball sampling technique. The researcher asked respondents to also refer him to other duplex owners known to them within the study area. Data was collected from these referrals, who are also asked to identify other people like them. Based on this approach, 156 questionnaires were administered out of which 138 were found usable. The unusable questionnaires were diagnosed with error of partial completion where key variables were missing.

The sample size of 138 tenants is considered reasonably adequate considering the fact that Nigeria property market is still evolving, the difficulty of data procurement and because of cross sectional homogeneity of the respondents. Furthermore, the socio-economic profile of purchasers of duplexes belong to the upper middle segment and the lower upper segment of the population income brackets that are supposed to have homogenous tastes such that the net effects of neighborhood attributes are similar. Secondary data were obtained from journals, technical reports, and previous studies.

Jacuzzi bathtubs effects are controlled by only comparing house with Jacuzzi bathtubs and house without Jacuzzi bathtubs. An actual Jacuzzi bathtub can range in size from a single person bath to multi-person Jacuzzi bathtubs; in this study, size of Jacuzzi bathtubs was ignored. The hedonic model is shown in Equation 1 below. All statistical procedures are performed in Statistical Package for Social Sciences (SPSS).

\section{Result}

Table 1.0: Variables Employed in the Hedonic Price Model and their Measurement 
The study utilized the linear functional form of the hedonic price model. Hedonic equations were specified with the sale price as the dependent variable and variables and sixteen explanatory variables. Table 1.0 below depicts the employed variables in the multiple regression model and their expected signs.

Models utilised in this study was specified as:

Price $=\beta_{0}+\beta_{1}($ NUMROOMS $)+\beta_{2}$ (NUMBATH $)+\beta_{3}($ SZLVGRM $)+\beta_{4}($ SZKIT $)+\beta_{5}($ CONSQUA $)+$ $\beta_{6}($ GARAGE $)+\beta_{7}(\mathrm{BQ})+\beta_{8}$ (SPOOL $)+\beta_{9}$ (PLOTSZ) $+\beta_{10}($ JACUZZI $)+\beta_{11}($ DISTWK $)+\beta_{12}($ AVASCH $)+$ $\beta_{13}($ AVASHOP $)+\beta_{14}($ AVAREG $)+\beta_{15}($ NEIGHSEC $)+\beta_{16}($ QUAENV $)+e \quad \quad . . . .$. equation 1.

$\mathrm{P}=$ sale price (duplexes)

$\beta_{1}$ to $\beta_{16}=$ coefficients to be estimated.

\section{Table 2.0 Descriptive Statistics of Variables}

Table 2.0 presents descriptive statistics for all the variables used in the analysis. From the table, the mean sales price of duplexes is N63,369,565 the minimum and maximum sales prices (PRICE) are N45,000.000 and $120,000,000$. The standard deviation is N38, 444,900. The mean of the number of rooms (NUMRM) is 4.21 while the minimum and maximum numbers of rooms are 3 and 6 respectively. The mean value of the number of bathrooms (NUMBATH) is 4.06 while the minimum and maximum numbers of bathrooms are 3 and 5 respectively. The size of living room (SZLVGRM) has a mean of $52.53 \mathrm{~m}^{2}$ while the minimum and maximum are $40 \mathrm{~m}^{2}$ and $81 \mathrm{~m}^{2}$ respectively. The size of kitchen has a minimum value of $14 \mathrm{~m}^{2}$ and $36 \mathrm{~m}^{2}$ as the maximum value. The mean is $20.91 \mathrm{~m}^{2}$ and a standard deviation is $6.02 \mathrm{~m}^{2}$.

\section{Table 3.0 $T$-test to determine if having a Jacuzzi bathtub affects the price of the house}

The key variable of interest is the effect of Jacuzzi bathtubs on house prices. Table 3.0 provides some cursory insight into the relationship. A $t$-test is performed to measure if there is a difference in the house price of homes with Jacuzzi bathtubs and homes without Jacuzzi bathtubs. The difference in house price is statistically significant $(\mathrm{N} 63,002,990-\mathrm{N} 57,670,980)=\mathrm{N} 5,332,010$ or 9.2\%. That is houses with Jacuzzi bathtubs command higher prices than houses without Jacuzzi bathtubs.

\section{Table 4.0 Hedonic Regression Analysis}

In order to control for the effects of other variables that might cause differences in house prices, hedonic price model must be performed. Table 4.0 below shows the hedonic regression results for the fourteen explanatory variables used against the dependent variable PRICE. The performance of the model is good as indicated by adjusted $\mathrm{R}^{2}$ statistics $(0.773)$. This shows that $77.3 \%$ of the sample variation in house prices in the study area could be attributed to the independent variables. The computed F-statistics $(\mathrm{F}=116.911)$ falls in the rejection region, signifying that at least one of the model coefficients is non-zero, thus the F-statistic shows the overall model to be significantly beyond the $1 \%$ level. Therefore the model appears to be useful for predicting house prices.

The key variable of interest is Jacuzzi bathtub, has a $t$-statistics of 3.613 versus the $95 \%$ level of significant which is 1.960 . The higher $t$-statistics of Jacuzzi bathtubs over the statistically significant cut-off demonstrates the significant positive relationship that exists between Jacuzzi bathtubs and house prices. To discuss the results in terms of Naira, the beta coefficients of 2,167,615 shows that after controlling for the relevant determinants of house prices, house with Jacuzzi bathtub are worth N2,167,615 more than house without a Jacuzzi bathtubs

\section{Table 5.0 Collinearity Statistics}

To verify that multicollinearity is not a problem, advanced diagnostic tests have been performed tolerance and variance inflation factor (VIF) was also performed. Tolerance values approaching zero indicate that the variable is too highly predicted, or is collinear with the other independent variables. The critical cut off value is 0.10 (Hair et al., 1995). A related reported value is the VIF. This is simply the reciprocal of the tolerance. For this reason, values below ten show that multicollinearity is not present. As seen in table 5.0 below, none of the variables come close to violating the no multicollinearity regression assumption.

\section{Conclusion}

Jacuzzi bathtubs should positively impact house prices. While this is logical the empirical research necessary to support this claim is somewhat limited. Most existing housing regression model always neglect Jacuzzi bathtubs in the hedonic regression model, the reason could be attributed to lack of awareness of the benefits of having a Jacuzzi bathtubs. 
This study empirically tests a hedonic house pricing model using a sample of 138 houses in high income residential sub-market in Lagos metropolis where some houses have Jacuzzi bathtubs while others do not. The results clearly demonstrate that houses with Jacuzzi have statistically significant impact on house prices even after adjusting for other significant house price determinants. The premium paid for houses with Jacuzzi bathtubs translates into $\mathrm{N} 2,167,615$. That is when valuing a house that has a Jacuzzi bathtubs, valuers should add $\mathrm{N} 2,167,615$ to their appraised valuation. Of course, not all Jacuzzis in the study area have the same. As such, the results of cannot be used as a cook-book to exactly determine the value of Jacuzzi bathtubs when valuing a house, there is therefore the need for upward or downward adjustment based on the size of the Jacuzzi bathtubs. This study provides a starting point from which valuers can deviate when assessing premium for Jacuzzi bathtubs in Lagos, Nigeria.

\section{References}

Adair, A., Berry, J. and McGreal, S. (1996). Valuation of Residential Property: Analysis of Participant Behavior. Journal of Property Valuation and Investment Vol.14 No.1 pp 20-35.

Adair, A., McGreal, S., Smyth, A., Cooper, J. and Ryley, T. (2000). 'House Prices and Accessibility: The Testing of Relationships within the Belfast Urban Area', Housing Studies, 15: 5, 699 - 716

Aluko, B.T. (1998). Examining Valuers's Judgement in Residential Property Valuation in Metropolitan Lagos, Nigeria. Property Management Vol. 25 No. 1 pp. 98-107

Bello V.A and Ajayi C.A (2010). Occupants' Satisfaction and Rent Paid for Residential Properties Close to Waste Dump Sites in Nigeria. Journal of Sustainable Development. Vol 3. No. 1. pp. 98-103.

Bello V.A and Bello M.O (2009). Valuation of Properties in Close Proximity to Waste Dumps Sites: The Nigeria Experience. International Journal of Strategic Property Management13, 309-317

Bello, M.O. and Bello, V.A. (2007). The Influence of Consumers Behaviour on the Variables Determining Residential Property Values in Lagos, Nigeria. American Journal of Applied Sciences 4(10): 774-778

Bello, M.O. and Bello, V.A. (2008). Willingness to pay for better environmental services: evidence from the Nigerian real estate market, Journal of African Real Estate Research, 1(1), pp. 19-27.

Benefield J.D. (2009). Neighbourhood Amenity Packages, Property Price, and Marketing Time. Property Management. Vol. 27 No.5 pp 348-370.

Benefield J.D and Weeks H.S. (2009). Price effects of speciality ceiling in residential real estate. The Appraisal Journal, Spring. pp. 117-125

Bourassa, S. C., Hoesli,M.\& Sun, J. (2004). What's in a view? Environment and Planning, 36(8), pp. $1427-1450$.

Brasington, D.M. (1999). "Which measures of school quality does the housing market value?", Journal of Real Estate Research, Vol. 18 No. 3, pp. 395-414.

Carrol T.M.., Clauretie T.M., \& Jensen J. (1996). Living Next to Godliness: Residential Property Values and Churches. Journal of Real Estate Finance and Economics, 12: 319-330.

Celik H.M and Yankaya U. (2006). The Impact of Rail Transit Investment on the Residential Property Values in Developing Countries. The Case of Izmir Subway, Turkey. Property Management Vol. 24, No. 24. pp. 369-382

Chau, C.K., Yung, H.K., Leung, T.M., Law, M.Y. (2006). Evaluation of relative importance of environmental issues associated with a residential estate in Hong Kong. Landscape Urban Plann. 77, 67-79.

Chau, K.W. and Ng, F.F. (1998). "The effects of improvement in public transportation capacity on residential price gradient in Hong Kong", Journal of Property Valuation \& Investment, Vol. 16 No. 4, pp. 397-410.

Clapp, J. M., and C. Giaccoto. (1998). Residential Hedonic Models: A Rational Expectations Approach to Age Effects," Journal of Urban Economics 44, 415 Y 437.

Clark, D.E. and Herrin, W.E. (2000). "The impact of public school attributes on home sale prices in California", Growth and Change, Vol. 31 No. 3, pp. 385-407.

Clauretie T.M, Kuhu W. and Schewer R.K. (2004). Residential Properties Taken Under Eminent Domain: Do Government Appraiser Track Market Values. Journal of Real Estate Estate Research Vol. 26 No 3 pp317-327

Daly J, Gronow S, Jenkins D and Plimmer F. (2003). Consumer Behaviour in the Valuation of Residential Property: A Study in the UK, Ireland and Australia. Property Management. Vol. 21 No.5

Des Rosiers, F. (2002). Power Lines, Visual Encumbrance and House Values: A Micro-spatial Approach to Impact Measurement, The Journal of Real Estate Research, 23(3): 275-300.

Des Rosiers, F. and M. Thériault (1996). Rental Amenities and the Stability of Hedonic Prices: A Comparative analysis of Five Market Segments, Journal of Real Estate Research, 12(1): 17-36. 
Des Rosiers, F., A. Lagana and M. Thériault. (2001). Size and Proximity Effects of Primary Schools on Surrounding House Values, Journal of Property Research, 18(2): 149-168.

Des Rosiers, F., A. Lagana, M. Thériault and M. Beaudoin. (1996). Shopping Centers and House Values: An Empirical Investigation, Journal of Property Valuation \& Investment, 14(4): 41-63.

Des Rosiers, F., Bolduc, A. and Theriault, M. (1999). "Does drinking water quality affect house prices?", Journal of Property Investment \& Finance, Vol. 17 No. 5, pp. 444-63.

Des Rosiers, F., M. Thériault and L. Ménétrier (2005): Spatial Versus Non-Spatial Determinants of Shopping Center Rents : Modeling Location and Neighborhood-Related Factors, Journal of Real Estate Research, 27(3): 293-319.

Des Rosiers, F., Theriault, M. and Villeneuve, P.Y. (2000). "Sorting out access and neighbourhood factors in hedonic price modeling", Journal of Property Investment \& Finance, Vol. 18 No. 3, pp. 291-315.

Epsey, M. and Owusu-Edusei, K. (2001). "Neighborhood parks and residential property values in Greenville, South Carolina", Journal of Agricultural and Applied Economics, Vol. 33 No. 3, pp. 487-92.

Fletcher M. Mangan J. And Raeburn E. (2004). Comparing Hedonic Models for Estimating and Forecasting House Prices. Property Management. Vol. 22 No3, pp. 189-200

Gallimore, P. and Wolverton, M. L. (1997). Price knowledge induced bias: a cross - cultural comparison. Journal of Property Valuation and Investment, 15 (3), 261-73.

Gao, X., Asami, Y. (2007). Effect of urban landscape on land prices in two Japanese cities. Landscape Urban Plann. 81,155-166.

Garrod, G.D., Willis, K.G. (1992). Valuing goods' characteristics: an application of the hedonic price method to environmental attributes. Journal of Environmental Management (34) 59-76.

Goodman, A.C. and Thibodeau, T.G. (1995). "Dwelling age heteroskedasticity in hedonic house price equations", Journal of Housing Research, Vol. 6 No. 1, pp. 25-42.

Goodman, A.C. and Thibodeau, T.G. (1997). "Dwelling age heteroskedasticity in hedonic price equations: an extension", Journal of Housing Research, Vol. 8 No. 2, pp. 299-317.

Goodman, A.C. and Thibodeau, T.G. (1998). "Housing market segmentation”, Journal of Housing Economics, Vol.7, pp. 121-43.

Grisson, T.A. (1991). Valuation without Comparables. The Appraisal Journal. 59: 370-376

Henneberry, J. (1998). Transport investment and house prices. Journal of Property Valuation and Investment 16 (2), 144-158.

Hooper PL. (1999). Hot-tub therapy for type 2 diabetes mellitus. N Engl J Med Sep 16;341(12):924-5.

Huh, S., and S.-J. Kwak. (1997). The Choice of Functional Form and Variables in the Hedonic Price Model in Seoul,"' Urban Studies 34, 989Y998.

Kauko T. (2003). Residential Property Value and Locational Externalities on the Complementarity and Substitutability of Approaches. Journal of Property Investment and Finance Vol. 21 No. 3 pp 250-270

Ketkar, K. (1992). Hazardous wastes sites and property values in the state of New Jersey, Applied Economics, 24(6), pp. 647-659.

Kohlhase, J. E. (1991). The impact of toxic wastes sites on housing values, Journal of Urban Economics, 30(4), pp. 1-26.

Komarova V. (2009). Valuing Environmental Impact of Air Pollution in Moscow with Hedonic Prices. World Academy of Science, Engineering and Technology 572009 pp319-326

Kryvobokov M. (2007). What Location Attributes are the Most Important for Market Value? Extraction of Attributes from Multiple Regression Models. Property Management Vol. 25 No.3 pp257-286.

Larsen J.E and Coleman J.W. (2010). Cemetry Proximity and Single-Family House Price. The Appraisal Journal Winter. pp. 33-49.

Mc Cluskey W.J and Borst R.A. (2007).Specifying the Effect of Location in Multivariate Valuation Models for Residential Properties. Property Management Vol. 25 No. 4. pp 312-343

Mok, H.M.K., Chan, P.P.K., Cho, Y.S. (1995). A hedonic price model for private properties in Hong Kong. $J$. Real Estate Finance Econ. 10, 37-48.

Ratchatakulpat, T. Miller P. And Marchant T. (2009). Residential Real Estate Purchase Decions in Australia: Is it more than Location? International Real Estate Review. Vol. 12 No 3: pp. 273-294.

Rosen, S. (1974). Hedonic prices and implicit markets: product differentiation in pure competition. J. Polit. Economy 82, 34-55.

Roulac, S.E. (2007). Brand + Beauty + Utility = Property Value, Property Management, 25, 5, 428-446 
Selim S. (2008). Determinants of House Prices in Turkey: A Hedonic Regression Model. Doğuş Üniversitesi Dergisi, 9 (1) 2008, 65-76

So, H.M., Tse, R.Y.C., Ganesan, S. (1997). Estimating the influence of transport on house prices: evidence from Hong Kong. J. Property Valuation Investment 15, 40-47.

Tse, R.Y.C. (2002). Estimating neighborhood effects in house prices: towards a new hedonic model approach. Urban Studies. 39, 1165-1180.

Tse, R.Y.C., Love, P.E.D. (2000). Measuring residential property values in Hong Kong. Property Management. $18,366-374$.

Tu Y. Ong S.E and Han Y.H. (2009). Turnovers and Housing Price Dynamics: Evidence from Singapore Condominium Market. Journal of Real Estate Finance Economics 38:254-274

Tyrväinen, L. (1997). The amenity value of the urban forest: an application of the hedonic pricing method. Landscape Urban Plann. 37, 211-222.

Tyrväinen, L., Miettinen, A. (2000). Property prices and urban forest amenities. Journal Environmental Economics Management. 39, 205-223.

Wolverton, M.L. (1997). "Empirical study of the relationship between residential lot price, size and view", Journal of Property Valuation \& Investment, Vol. 15 No. 1, pp. 48-57.

Wyman D and S;perry s. (2010). The Million Dollar View: A study of Golf Course, Mountain, and Lake Lots. The Appraisal Journal, Spring. 159-168

Yang, Z. (2001). "An application of the hedonic price model with uncertain attribute: the case of the People's Republic of China", Property Management, Vol. 19 No. 1, pp. 50-63.

Table 1. Variables Employed in the Hedonic Price Model and their Measurement

\begin{tabular}{|c|c|c|c|}
\hline S/no & Variables Definition & Variables Code & Variable Measurements \\
\hline 1. & $\begin{array}{l}\text { Property price: Dependent } \\
\text { Variable }\end{array}$ & PRICE & Measure in Naira \\
\hline 2. & Number of rooms & NUMROOMS (+) & Numbers \\
\hline 3. & Number of bathrooms & NUMBATH $(+)$ & Numbers \\
\hline 4. & Size of living rooms & SZLVGRM (+) & In $\mathrm{m}^{2}$ (approximately) \\
\hline 5. & Size of kitchen & SZKIT $(+)$ & In $\mathrm{m}^{2}$ (approximately) \\
\hline 6. & Construction quality & CONSQUA (+) & Dummy variable 1 for good $\& 0$ otherwise \\
\hline 7. & Garage & GARAGE (+) & Dummy variable 1 for availability $\& 0$ otherwise \\
\hline 8. & Boys' quarters & $\mathrm{BQ}(+)$ & Dummy variable 1 for availability $\& 0$ otherwise \\
\hline 9. & Swimming pool & SPOOL $(+)$ & Dummy variable 1 for availability $\& 0$ otherwise \\
\hline 10. & Plot size & PLOTSZ $(+)$ & In $\mathrm{m}^{2}$ (approximately) \\
\hline 11. & Jacuzzi & JACUZZI (+) & Dummy variable 1 for availability \& 0 otherwise \\
\hline 12. & Distance to place of work & DISTWK (-) & In km (approximately) \\
\hline 13. & $\begin{array}{l}\text { Availability of quality } \\
\text { school }\end{array}$ & AVASCH $(+)$ & $\begin{array}{l}\text { Dummy variable } 1 \text { for quality schools within } 2 \mathrm{~km} \\
\& 0 \text { otherwise }\end{array}$ \\
\hline 14. & Availability of shops & AVASHOPS $(+)$ & $\begin{array}{l}\text { Dummy variable } 1 \text { for availability within } 2 \mathrm{~km} \mathrm{\&} \\
0 \text { otherwise }\end{array}$ \\
\hline 15. & $\begin{array}{l}\text { Availability of recreational } \\
\text { facilities }\end{array}$ & AVAREC (+) & Dummy variable 1 for availability \& 0 otherwise \\
\hline 16. & Neighborhood security & NEIGHSEC (+) & Dummy variable 1 for good \& 0 otherwise \\
\hline 17. & Quality of environment & QUAENV (+) & Dummy variable 1 for good \& 0 otherwise \\
\hline
\end{tabular}


Table 2. Descriptive Statistics of Variables

\begin{tabular}{|c|c|c|c|c|}
\hline Variables & MINIMUM & MAXIMUM & MEAN & S.D \\
\hline PRICE (Naira) & $45,000,000$ & $120,000,000$ & 63,369565 & $38,444,900$ \\
\hline NUMROOM & 3 & 6 & 4.21 & 0.62 \\
\hline NUMBATH & 3.00 & 5.00 & 4.06 & 0.48 \\
\hline $\operatorname{SZLVGRM}\left(\mathrm{m}^{2}\right)$ & 40.00 & 81.00 & 52.53 & 18.02 \\
\hline $\operatorname{SZKIT}\left(\mathrm{m}^{2}\right)$ & 14.00 & 36.00 & 20.91 & 16.48 \\
\hline CONSQUA & 0.00 & 1.00 & 0.67 & 0.45 \\
\hline GARAGE & 1.00 & 6.00 & 2.45 & 1.65 \\
\hline $\mathrm{B} / \mathrm{Q}$ & 0.00 & 1.00 & 0.50 & 0.36 \\
\hline SPOOL & 0.00 & 1.00 & 0.34 & 0.47 \\
\hline $\operatorname{PLTSZ}\left(\mathrm{m}^{2}\right)$ & 555 & 2275 & 766 & 311 \\
\hline JACUZZI & 0.00 & 1.00 & 0.71 & 0.45 \\
\hline DISTWK(km) & 0.30 & 6.00 & 3.04 & 1.01 \\
\hline AVASCH & 0.00 & 1.00 & 1.90 & 1.28 \\
\hline AVASHOP & 0.50 & 1.00 & 0.74 & 0.52 \\
\hline AVAREC & 0.00 & 1.00 & 0.50 & 0.39 \\
\hline NEIGHSEC & 0.00 & 1.00 & 0.60 & 0.28 \\
\hline QUAENV & 0.00 & 1.00 & 0.57 & 0.50 \\
\hline
\end{tabular}

Table 3. $T$-test to determine if having a Jacuzzi bathtub affects the price of the house

\begin{tabular}{lccccc}
\hline & Jacuzzi & N & Mean & Std. Deviation & F-test Sig. \\
House Price & Yes & 46 & $63,002,990$ & $31,150,765$ & 128.062 \\
& No & 92 & $57,670,980$ & $12,300,120$ & 0.000 \\
\hline
\end{tabular}


Table 4. Hedonic Regression Analysis

\begin{tabular}{|c|c|c|c|c|c|}
\hline Variables & Unstd Beta & Std error & Std Beta & $t$ & Sig \\
\hline Constant & 4311098.790 & 1125455.279 & & 3.831 & 0.000 \\
\hline NUMROOM & 1313414.416 & 220650.349 & 0.629 & 5.952 & 0.000 \\
\hline NUMBATH & 870672.493 & 311678.570 & 0.216 & 2.793 & 0.040 \\
\hline SZLVGRM & 88992.344 & 18369.449 & 0.477 & 4.845 & 0.020 \\
\hline SZKIT & 75100.219 & 33157.841 & 0.268 & 2.265 & 0.050 \\
\hline CONSQUA & 1625894.157 & 751009.468 & 0.266 & 2.165 & 0.040 \\
\hline GARAGE & 386601.814 & 143215.350 & 0.028 & 2.699 & 0.040 \\
\hline BQ & 4383830.809 & 722890.235 & 0.477 & 6.064 & 0.000 \\
\hline SPOOL & 4278856.854 & 1738011.434 & 0.541 & 2.462 & 0.030 \\
\hline PLOTSZ & 120890 & 46660.647 & 0.256 & 2.591 & 0.050 \\
\hline JACUZZI & 2167615.887 & 600009.764 & 0.473 & 3.613 & 0.050 \\
\hline DISTWK & -890654.659 & 299540.380 & -0.386 & -2.973 & 0.030 \\
\hline AVASCH & 784321.779 & 245220.971 & 0.137 & 3.198 & 0.000 \\
\hline AVASHOP & 745381.889 & 623711.800 & 0.119 & 1.195 & 0.080 \\
\hline AVAREC & 689000.874 & 265098.439 & 0.243 & 2.599 & 0.020 \\
\hline NEIGHSEC & 380976.344 & 121547.300 & 0.171 & 3.135 & 0.040 \\
\hline QUAENV & 450731.090 & 126890.409 & 0.027 & 3.552 & 0.010 \\
\hline \multicolumn{6}{|l|}{ Adj R² 0.773; } \\
\hline \multicolumn{6}{|l|}{ F-stat 56.911; } \\
\hline \multicolumn{6}{|c|}{ Durbin Watson 1.937; } \\
\hline Number 138 & & & & & \\
\hline
\end{tabular}


Table 5. Collinearity Statistics

\begin{tabular}{lcc}
\hline Variables & TOLERANCE & VIF \\
\hline NUMROOM & 0.508 & 1.169 \\
NUMBATH & 0.863 & 1.159 \\
SZLVGRM & 0.689 & 1.452 \\
SZKIT & 0.833 & 1.299 \\
CONSQUA & 0.911 & 1.211 \\
GARAGE & 0.810 & 1.379 \\
BQ & 0.735 & 1.126 \\
SPOOL & 0.823 & 1.312 \\
PLOTSZ & 0.957 & 1.222 \\
JACUZZI & 0.825 & 1.237 \\
DISTWK & 0.789 & 1.186 \\
AVASCH & 0.617 & 1.620 \\
AVASHOP & 0.821 & 1.218 \\
AVAREC & 0.680 & 1.471 \\
NEIGHSEC & 0.741 & 1.350 \\
QUAENV & 0.891 & 1.098 \\
\hline
\end{tabular}

